\title{
APPLICATION OF ANTIOXIDANTS AND EDIBLE STARCH COATING TO REDUCE BROWNING OF MINIMALLY-PROCESSED CASSAVA ${ }^{1}$
}

\author{
DANIEL GOMES COELHO ${ }^{2}$, MOAB TORRES DE ANDRADE $^{2}$, DOMINGOS FERREIRA DE MÉLO NETO ${ }^{2}$, SÉRGIO \\ LUIZ FERREIRA-SILVA ${ }^{3}$, ADRIANO DO NASCIMENTO SIMÕES ${ }^{3 *}$
}

\begin{abstract}
This study aimed to evaluate the quality of minimally-processed cassava treated with antioxidants and a starch-based edible coating. Cassava roots were washed, cooled, immersed in cold water, peeled and then cut. Root pieces were then immersed in a chloride solution, centrifuged, and subsequently immersed in either a starch suspension (3\%), a solution containing antioxidants (3\% citric acid and $3 \%$ ascorbic acid), or in both the coating and antioxidant solutions. Coated root pieces were dried at $18 \pm 2{ }^{\circ} \mathrm{C}$ for 1 hour, then packaged into polypropylene bags $\left(150 \mathrm{~g}\right.$ per pack) and kept at $5 \pm 2{ }^{\circ} \mathrm{C}$ for 15 days, and assessed every 3 days. A completely randomized design was used in a $4 \times 6$ factorial consisting of the treatment (control, coating, antioxidant, or coating and antioxidant) and the storage period ( $0,36,9,12$ or 15 days), with three replicates in each group. The $\mathrm{pH}$, blackened area and peroxidase and polyphenol oxidase activities of the cassava was reduced in treatments containing antioxidants and the scores of visual analysis and phenolic content were higher. Therefore, treatment with antioxidants was effective for reducing browning in minimallyprocessed cassava, retaining the quality of cassava pieces stored for 15 days at $5 \pm 2{ }^{\circ} \mathrm{C}$. The combination of antioxidants and the edible coating showed no improvement compared to treatment with antioxidants alone.
\end{abstract}

Keywords: Manihot esculenta Crantz. Physiological changes. Postharvest.

\section{ESCURECIMENTO EM MANDIOCA DE MESA MINIMAMENTE PROCESSADA COM USO DE ANTIOXIDANTES E REVESTIMENTO DE AMIDO}

RESUMO - Objetivou-se avaliar a qualidade de mandioca de mesa minimamente processada com o uso de antioxidantes e revestimento comestível a base de amido. Raízes de mandioca de mesa foram lavadas, resfriadas, imersas em água fria, cortadas e descascadas. Os pedaços foram imersos em solução clorada, centrifugados e imersos em suspensão de amido (3\%) ou em solução contendo antioxidantes (ácido cítrico 3\% e ácido ascórbico 3\%) ou em ambos (revestimento + antioxidantes). Os pedaços contendo revestimento foram secos em sala climatizada a $18 \pm 2{ }^{\circ} \mathrm{C}$ por 1 hora. Os pedaços foram embalados em polipropileno, contendo 150 g por embalagem, e mantidos a $5 \pm 2{ }^{\circ} \mathrm{C}$ por 15 dias, com avaliações a cada três dias. Foi utilizado o DIC, em esquema fatorial $4 \times 6$ [controle, revestimento, antioxidantes e revestimento + antioxidantes $\mathrm{x}$ dias de conservação $(0 ; 36 ; 9 ; 12$ e 15 dias)] com 3 repetições. Verificou-se que os valores de $\mathrm{pH}$, área escurecida e as atividades da peroxidase e polifenoloxidase foram menores e as notas da análise visual e o teor de fenólicos totais foram superiores nos tratamentos contendo antioxidantes. $\mathrm{O}$ uso dos antioxidantes foi eficiente na redução do escurecimento em mandioca de mesa minimamente processada, mantendo os pedaços com qualidade por 15 dias a $5 \pm 2{ }^{\circ} \mathrm{C}$ e a associação de antioxidantes e revestimento comestível não apresentou melhorias em comparação aos antioxidantes isolados.

Palavras-chave: Manihot esculenta Crantz. Alterações fisiológicas. Pós-colheita.

\footnotetext{
*Corresponding author

${ }^{1}$ Received for publication in 04/12/2016; accepted in 09/14/2016

Paper extracted from the conclusion of course work of the first author.

${ }^{2}$ Departament of Agronomy, Universidade Federal do Ceará, Fortaleza, CE, Brazil; danielcoelho.ea@gmail.com, moab.agro@gmail.com, domingosnetto@hotmail.com.

${ }^{3}$ Unidade Acadêmica de Serra Talhada, Universidade Federal Rural de Pernambuco, Serra Talhada, PE, Brazil; agrosergol@yahoo.com.br, adriano.simoes@ufrpe.br.
} 


\section{INTRODUCTION}

Enzymatic browning is a phenomenon characterized by the formation of bluish, brownish or dark-colored streaks in whole, cut or minimally-processed vegetables, damaging the product quality and its commercial value. In roots, streaks are formed near the vascular tissue in response to a series of metabolic changes caused by environmental stress or post-harvest handling. In the case of minimally-processed roots, physical changes and hygiene and storage conditions can also induce these metabolic changes (OWITI et al., 2011; FREIRE et al., 2015). Reactions that cause browning may start a few hours after processing, and are mainly attributed to the oxidation of phenols by polyphenol oxidase (PPO) and peroxidase (POD) enzymes (TOMÁS-BARBERÁN; ESPIN, 2001).

One challenge in the control of enzymatic browning in foods is finding low-cost substances that preserve visual characteristics and pose no toxic effects to human health. Edible coatings based on starch and antioxidants, such as ascorbic and citric acid, provide these benefits (JIMÉNEZ et al., 2012; LI, WILLS; GOLDING, 2015; OJEDA; SGROPPO; ZARITZKY, 2014).

Botrel et al. (2010) found that a starch-based coating was effective for controlling the browning of minimally-processed pears. Mélo Neto et al. (2013) tested the effect of different concentrations of starch in coatings during the storage of minimally-processed cassava, however, browning was not effectively controlled in their study, with only fresh matter loss reduction.

The use of antioxidants, particularly citric acid and ascorbic acid, was found to be effective for reducing post-harvest browning for up to 9 days of storage in minimally processed-cassava of the "Cacauzinha" cultivar in a study by Medeiros (2009). Furthermore, Fernandes et al. (2014) found that combined use of ascorbic and citric acid (3\% for each) retained the quality of minimally-processed Arracacia xanthorrhiza for up to 8 days of storage.

In minimally-processed cassava, the use of antioxidants in isolation has had satisfactory results. However, their combined use with an edible coating may further prolong the useful-life of cassava post-harvest. Thus, the aim of this study was to evaluate the quality of minimally-processed cassava treated with antioxidants and a starch-based edible coating.

\section{MATERIAL AND METHODS}

Cassava roots of the "Mossoró" cultivar were harvested at 14 months in the experimental field of the Unidade Acadêmica de Serra Talhada, Universidade Federal Rural de Pernambuco (UAST/ UFRPE). The roots were transported, selected, rinsed with water, then cooled for 24 hours at $10 \pm 2{ }^{\circ} \mathrm{C}$.

Minimum processing was performed, based on the flowchart defined by Andrade (2013). Each cassava root was weighed, immersed in cold water for 5 minutes, manually peeled, then cut transversely every $3 \mathrm{~cm}$ followed by cutting in a longitudinal direction to form "small billets". Pieces were immersed for 10 seconds in water at $5^{\circ} \mathrm{C}$, followed by immersion for 10 minutes in an active chlorine solution $\left(200 \mathrm{mg} . \mathrm{L}^{-1}\right)$ then for 10 minutes in chlorinated water $\left(5 \mathrm{mg} . \mathrm{L}^{-1} ; 5^{\circ} \mathrm{C}\right)$. An $800 \mathrm{~g}$ sample was centrifuged for 30 seconds at $1756 \mathrm{~g}$, then divided into four batches. The first batch was immersed in the cassava starch suspension at a concentration of $3 \%$, obtained from the gelatinization of cassava starch heated to $70^{\circ} \mathrm{C}$. The second batch was immersed in a solution containing $3 \%$ ascorbic acid (w/v) and $3 \%$ citric acid (w/v). The third batch was immersed in the antioxidant solution described above, then in the starch suspension. The final batch acted as the control, with no immersion performed. The coated pieces were dried for 1 hour in a room at $18 \pm 2{ }^{\circ} \mathrm{C}$ with forced ventilation. Approximately $150 \mathrm{~g}$ of each batch was packaged into polypropylene bags $(150 \times 200 \mathrm{~mm}, 0.6 \mu \mathrm{m}$ thick), and stored for 15 days at $5 \pm 2{ }^{\circ} \mathrm{C}$ with $90 \pm$ $5 \%$ relative humidity (RH). Assessments were conducted every 3 days after processing, beginning on day 0 , then at 3,6,9,12 and 15 days.

Quality visual scores was performed by four trained evaluators, taking into account the presence or absence of dark spots on the tissue surface, yellow -green discoloration and a sticky consistency, all of which are characteristic of Pseudomonas sp. contamination. In addition, the presence of a fermented odor and whitening of the pieces, related to starch precipitation, was recorded. These characteristics were subjectively scored on a scale ranging from 1 to 5 , based on that described by Andrade (2013), in which each piece received a score and the average value for each pack was calculated (Table 1). 
D. G. COELHO et al.

Table 1. Illustrations, grades and criteria used to quantify visual changes in minimally processed sweet cassava.

\begin{tabular}{|c|c|}
\hline Grades & 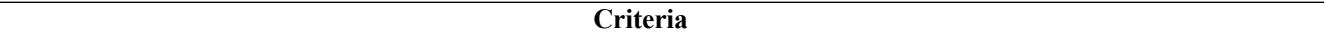 \\
\hline & $\begin{array}{l}\text { Pieces with white surface characteristic, appearance and odor excellent for consumption, having enough quality for } \\
\text { commercialization }\end{array}$ \\
\hline & Light browning evidence, having enough quality for commercialization \\
\hline & Moderate browning intensity, limit of acceptance \\
\hline & Greenish-yellow coloring on the surface, characteristic of Pseudomonas spp., sticky surface \\
\hline & $\begin{array}{l}\text { All the symptoms described, and alcoholic odor, whitening on the surface, with dehydration; totally inappropriate for } \\
\text { consumption. }\end{array}$ \\
\hline
\end{tabular}

The darkened area was determined according to Oliveira et al. (2010) with modifications. Images of the cassava pieces were captured using a Nikon D3100 (Tokyo, Japan) digital camera without the flash, and analyzed with QUANT version 1.1 software (VALE et al., 2001). Results were expressed in $\mathrm{cm}^{2}$.

Fresh matter loss was obtained from the percentage difference between the weight of fresh matter at day 0 (initial weight) and the evaluation day (final weight) using the following equation: $\mathrm{FML}=[(\mathrm{iM}-\mathrm{fM}) / \mathrm{iM}] * 100$, where FML is the fresh matter loss (\%), iM is the initial weight of fresh matter $(\mathrm{g})$, and $\mathrm{fM}$ is the final weight of fresh matter (g). The results were expressed as a percentage. The $\mathrm{pH}$ was measured using an Ionlab (Araucária, Brazil) PHB 500 benchtop $\mathrm{pH}$ meter, according to the method described by the AOAC (1997).

The total soluble phenol content was determined using the method described by Folin and Ciocalteu (1927), adapted for cassava according to modifications by Freire et al. (2015). A sample of $0.25 \mathrm{~g}$ cassava was macerated in $1.5 \mathrm{~mL}$ methanol. The extract was kept in the dark at a temperature of $5^{\circ} \mathrm{C}$ for 24 hours. Afterwards, it was centrifuged (Universal 320R; Hettich, Berlin, Germany) at 7690 $g$ for 21 minutes at $2^{\circ} \mathrm{C}$.

Testing was carried out by the reaction of 150 $\mu \mathrm{L}$ of the methanol extract, diluted with $2.4 \mathrm{~mL}$ of distilled water, with $150 \mu \mathrm{L}$ of Folin and Ciocalteu reagent $(0.25 \mathrm{~N})$. After 3 minutes of mixture homogenization, $300 \mu \mathrm{L}$ of sodium carbonate $(1 \mathrm{~N})$ was added, stirred for 1 minute, then maintained in the dark at $20 \pm 5^{\circ} \mathrm{C}$ for 2 hours. Absorbance readings were performed at $725 \mathrm{~nm}$ using a spectrophotometer (Libra S8; Biochrom, London,
United Kingdom). The total soluble phenol content was quantitated from a gallic acid standard curve and expressed as mmol of gallic acid equivalents (GAE).kg Fresh Wheight (FW) ${ }^{-1}$.

Extraction of PPO and POD was conducted according to the methodology described by Medeiros (2009). Homogenization of $0.25 \mathrm{~g}$ of superficial tissue was conducted $( \pm 2 \mathrm{~mm})$ in $1.2 \mathrm{~mL}$ of $0.2 \mathrm{M}$ sodium phosphate buffer ( $\mathrm{pH}$ 6.0), which had been maintained at $4^{\circ} \mathrm{C}$. The extract was centrifuged (Mikro 220; Hettich, Berlin, Germany) at 10,000 $g$ for 21 minutes at $4^{\circ} \mathrm{C}$.

The PPO assay was performed according to Medeiros (2009). A sample of $100 \mu \mathrm{L}$ of supernatant was added to the reaction mixture containing $1.5 \mathrm{~mL}$ of $0.2 \mathrm{M}$ phosphate buffer ( $\mathrm{pH} 6.0$ ) and $1.3 \mathrm{~mL}$ of $0.2 \mathrm{M}$ catechol, which had been maintained at $20^{\circ} \mathrm{C}$ using a dry bath (Uniscience). Measurements were conducted at $425 \mathrm{~nm}$ using a spectrophotometer at $20^{\circ} \mathrm{C}$ for 2 minutes, with 10 -second intervals between readings. The PPO activity was calculated based on the molar extinction coefficient of 3400 $\mathrm{M} . \mathrm{cm}^{-1}$ for catechol, and expressed as $\mu \mathrm{mol} . \mathrm{min}^{-1} . \mathrm{g}$ $\mathrm{FW}^{-1}$.

Determination of POD activity was performed according to Simões et al. (2015). A sample of $100 \mu \mathrm{L}$ of supernatant was added to the reaction mixture containing $1 \mathrm{~mL}$ of $0.2 \mathrm{M}$ phosphate buffer ( $\mathrm{pH} 6.0), 100 \mu \mathrm{L}$ of guaiacol $(0.5 \%)$ and $100 \mu \mathrm{L}$ of hydrogen peroxide $(0.08 \%)$, previously maintained at $25^{\circ} \mathrm{C}$ in a dry bath. Measurements were taken at $470 \mathrm{~nm}$ using a spectrophotometer at $25^{\circ} \mathrm{C}$ for 3 minutes, with 30 -second intervals between readings. The POD activity was calculated based on the molar extinction coefficient of $26.6 \mathrm{mM} . \mathrm{cm}^{-1}$ for guaiacol, and 
expressed as nmol.min ${ }^{-1}$. $\mathrm{g} \mathrm{FW}^{-1}$.

A completely randomized $4 \times 6$ factorial study design was used. The first factor consisted of the coating treatment (control, coating, antioxidant, or coating and antioxidant), and the second factor was the storage period $(0,3,6,9,12$ or 15 days of storage), with three repetitions of $150 \mathrm{~g}$ per pack. Data were subjected to analysis of variance
(ANOVA) using Sisvar version 5.6 software (FERREIRA, 2011), in addition to determining the mean and standard deviation.

\section{RESULTS AND DISCUSSION}

The quality visual scores decreased over increasing storage periods (Figure 1).

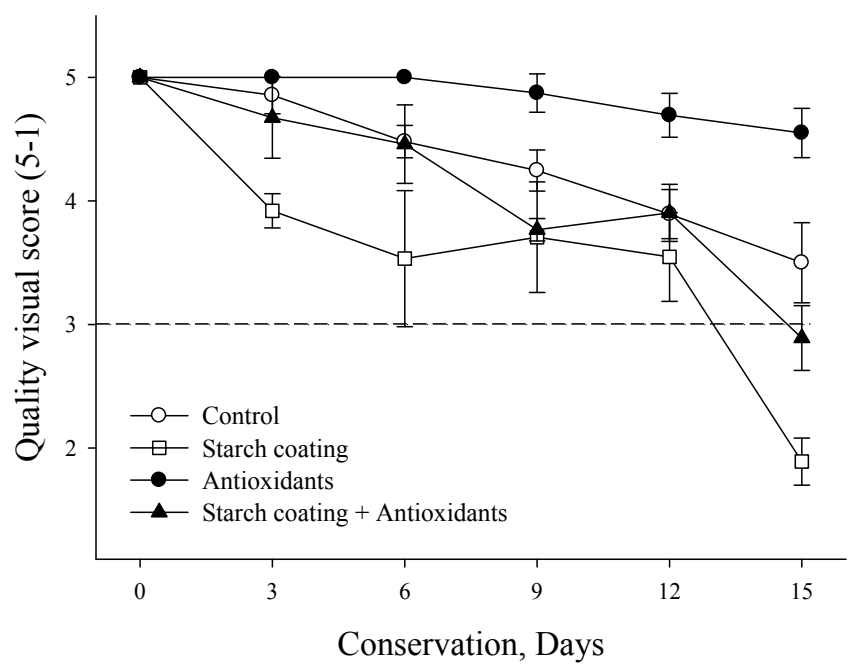

Figure 1. Quality visual score on fresh-cut sweet cassava, at $0,3,6,9,12$ and 15 days at $5 \pm 2^{\circ} \mathrm{C}$ and $90 \pm 5 \% \mathrm{RH}$. The edible coating containing cassava starch (3\%) and antioxidants (Citric acid, $3 \%+$ Ascorbic acid, $3 \%$ ), and control (whithout edible coating and antioxidants).

Pieces that were immersed in the solution only containing the antioxidants had the highest scores for all assessment days, due to decreased browning of these pieces. Similar results were reported by Lee, Lee and Park (2007) and Aguila et al. (2008), who observed a positive effect of ascorbic and citric acid when used individually on the control of browning in minimally-processed sliced taro and radishes, respectively.

The lowest scores were found for treatments including the starch coating, alone or combined with antioxidants, which showed scores of below 3 to 15 days, which are considered to be lower than the commercial acceptance limit (ANDRADE, 2013). These scores may be related to the exposure time during coating and drying, which may accelerate the reactions that cause browning. The drying time for the coating is necessary but harmful, as the product is exposed to room temperature for several minutes or hours. In the current study the drying time was limited to 1 hour. In a previously study with carrots, aimed at minimizing whitening, 2.5 hours of drying was required, even though the coating adjuvants stimulate the production of phenolic compounds, thereby slowing the deterioration symptoms (SIMÕES et al., 2009). Thus, studies that have investigated methods to accelerate this process are required to the evaluate the use of starch-based coatings (OJEDA; SGROPPO; ZARITZKY, 2014).

The lowest browning values during preservation were found for the treatments that contained the antioxidants (Figure 2), supporting the results obtained from the visual evaluation (Figure 1).

Treatments that contained both the coating and antioxidants obtained higher values at 12 and 15 days of storage than those only treated with antioxidants (Figure 2). The highest browning values were observed for the control pieces and those that had been immersed in the starch-based cassava coating (Figure 2). The high browning values suggest that the application and drying methodologies used in this study were not effective, or that the interaction between the surface of the cassava and the coating was not sufficient for the control of browning. Furtado (2013) studied minimally-processed yam, also finding that the use of a starch-based coating, even with the addition of antioxidants, was not effective for controlling enzymatic browning.

The fresh matter loss was higher over increasing days of storage, with values of between 0.05 and $0.15 \%$ obtained at 15 days (Figure 3 ). 


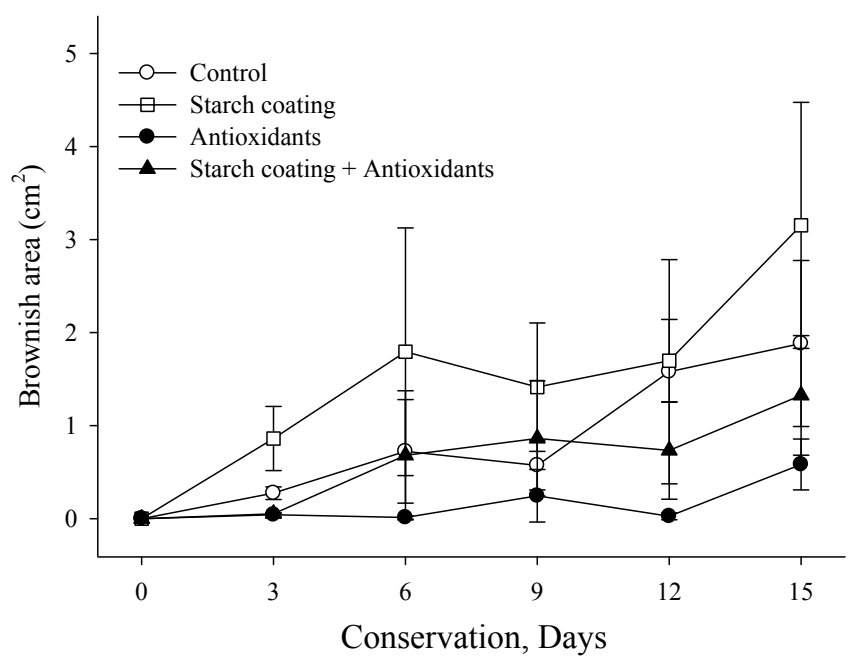

Figure 2. Brownish area $\left(\mathrm{cm}^{2}\right)$ on fresh-cut sweet cassava, at $0,3,6,9,12$ and 15 days at $5 \pm 2{ }^{\circ} \mathrm{C}$ and $90 \pm 5 \% \mathrm{RH}$. The edible coating containing cassava starch (3\%) and antioxidants (Citric acid, $3 \%+$ Ascorbic acid, $3 \%$ ), and control (whithout edible coating and antioxidants).

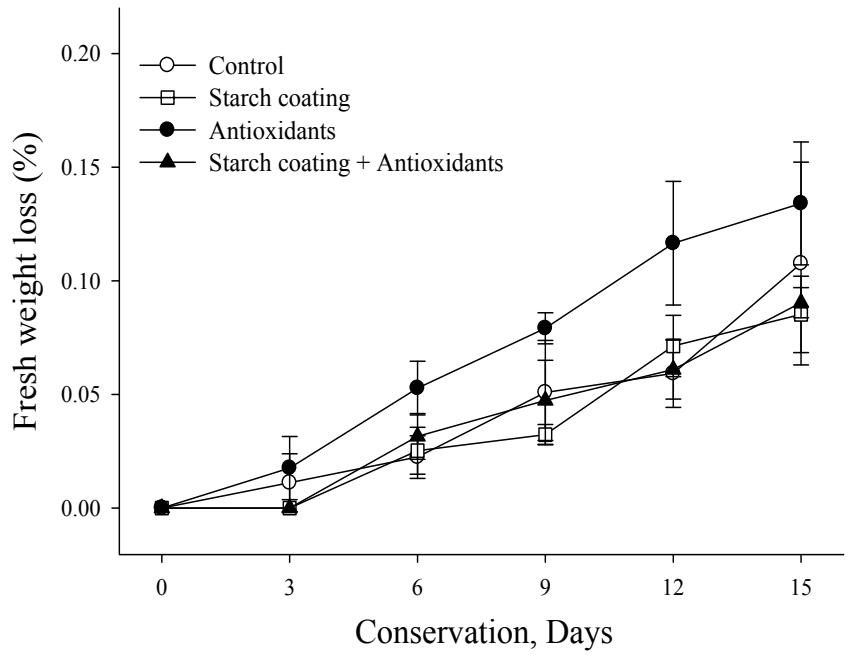

Figure 3. Fresh weight loss (\%) on fresh-cut sweet cassava, at 0,3, 6, 9, 12 and 15 days at $5 \pm 2^{\circ} \mathrm{C}$ and $90 \pm 5 \% \mathrm{RH}$. The edible coating containing cassava starch (3\%) and antioxidants (Citric acid, $3 \%+$ Ascorbic acid, $3 \%$ ), and control (whithout edible coating and antioxidants).

The treatments containing the cassava starch coating and the starch coating combined with antioxidants obtained lower percentage mass loss than the control treatment, however, no significant differences were observed over the storage period (Figure 3). This is possibly due to the hygroscopic nature of starch, as the films formed provide a poor barrier against water vapor loss, unlike coatings based on waxes and oils (BOURTOOM, 2008). On the other hand, due to the linearity of amylose molecules in solution, which favors a parallel orientation for film formation, starch coatings have good mechanical properties (MALI; GROSSMAN, YAMASHITA, 2010). Furthermore, interactions between the coating and the plant surface may affect permeability. In a study using papaya, characterized by its waxy surface, application of a starch coating was found to promote reduced fresh matter loss
(CAMPOS; KWIATKOWSKI; CLEMENTE, 2011). However, Botrel et al. (2007) did not observed lower matter loss when a starch coating was applied to minimally-processed garlic.

The highest values for matter loss over the storage period were observed for the treatments containing antioxidants (Figure 3). Similar results have been previously obtained by Furtado (2013) in yam treated with ascorbic acid, which had higher matter loss compared to yam only immersed in distilled water. The results obtained in the current study suggest a possible effect of ascorbic acid promoting an increase in respiratory metabolism of cassava, as the reduced $\mathrm{pH}$ caused by antioxidants promotes higher membrane $\mathrm{H}^{+}$-ATPase activity due to the increased $\mathrm{H}^{+}$concentration in the cell, resulting in increased cell respiration (ROCCULI et al., 2007). However, all values obtained for matter 
loss were below $1 \%$ (Figure 3 ), probably due to the use of packaging with a high barrier against loss of water vapor and gases, therefore, dehydration did not contribute to the loss in quality.
The $\mathrm{pH}$ was close at 6.0 for all treatments, except for pieces immersed in antioxidants only, which had a $\mathrm{pH}$ of approximately 5.5 during the storage period (Figure 4).

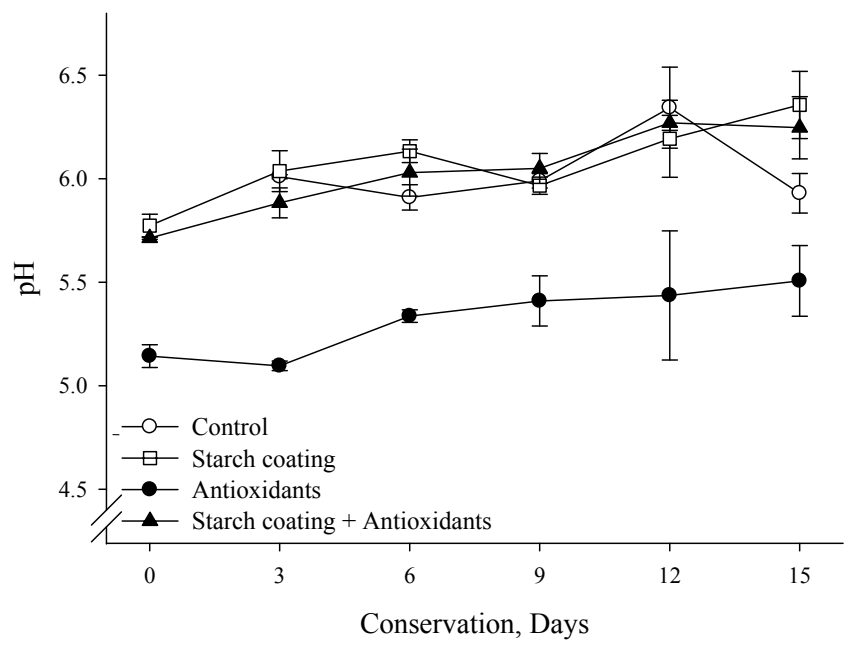

Figure 4. PH on fresh-cut sweet cassava, at $0,3,6,9,12$ and 15 days at $5 \pm 2^{\circ} \mathrm{C}$ and $90 \pm 5 \% \mathrm{RH}$. The edible coating containing cassava starch (3\%) and antioxidants (Citric acid, $3 \%+$ Ascorbic acid, $3 \%$ ), and control (whithout edible coating and antioxidants).

The reduction in $\mathrm{pH}$ observed in this treatment group can be attributed to citric acid, which may reduce polyphenoloxidase (enzyme involved in the formation of blackened compounds) activity by up to $40 \%$ when the $\mathrm{pH}$ is below 6 (DUANGMAL; APENTEN, 1999; LIMBO; PIERGIOVANNI, 2006). Shah and Nath (2008), in a study on lychees, and Junqueira et al. (2009), who incorporated ascorbic and citric acid into active films to store potatoes, also found that the $\mathrm{pH}$ reduction resulting from addition of antioxidants reduced enzymatic browning.

The total soluble phenol content decreased during the storage period in minimally processed cassava (Figure 5), possibly due to oxidative processes.

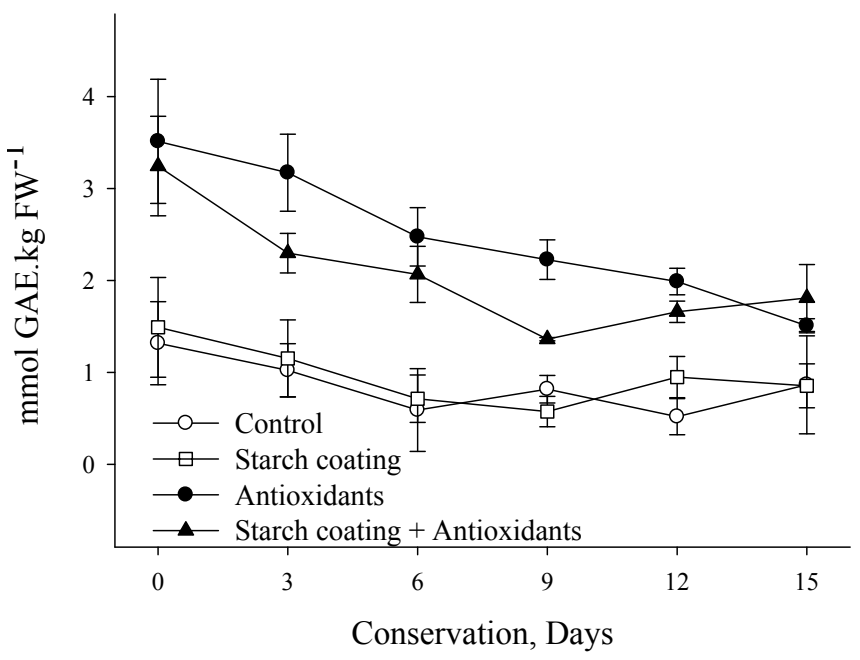

Figure 5. Total soluble phenolics on fresh-cut sweet cassava, at $0,3,6,9,12$ and 15 days at $5 \pm 2^{\circ} \mathrm{C}$ and $90 \pm 5 \% \mathrm{RH}$. The edible coating containing cassava starch (3\%) and antioxidants (Citric acid, $3 \%+$ Ascorbic acid, $3 \%$ ), and control (whithout edible coating and antioxidants). GAE: Gallic Acid Equivalent.

At the start of the storage period (day 0 ), the total soluble phenol content was on average 2.25-times higher for the treatments containing antioxidants, alone or when combined with the starch coating. The higher total soluble phenol content suggests that there was lower phenol oxidation compared to the control treatment and the treatment with the starch coating only. This can be explained by the reducing action of ascorbic acid, among other factors, as quinones oxidized by enzymatic activity are reduced again to phenolic compounds (AKA et al., 2013). Therefore, this may have contributed to the reduction in enzymatic

Rev. Caatinga, Mossoró, v. 30, n. 2, p. 503 - 512, abr. - jun., 2017 
browning observed in pieces only treated with antioxidants (Figures 1 and 2).

On the other hand, treatments containing the antioxidants and the coating had a higher reduction in phenol content during the storage period compared to those treated with the antioxidants only, which was associated with injuries resulting from the drying process.

In relation to the PPO activity, it was generally found to increase over the storage period (Figure 6).

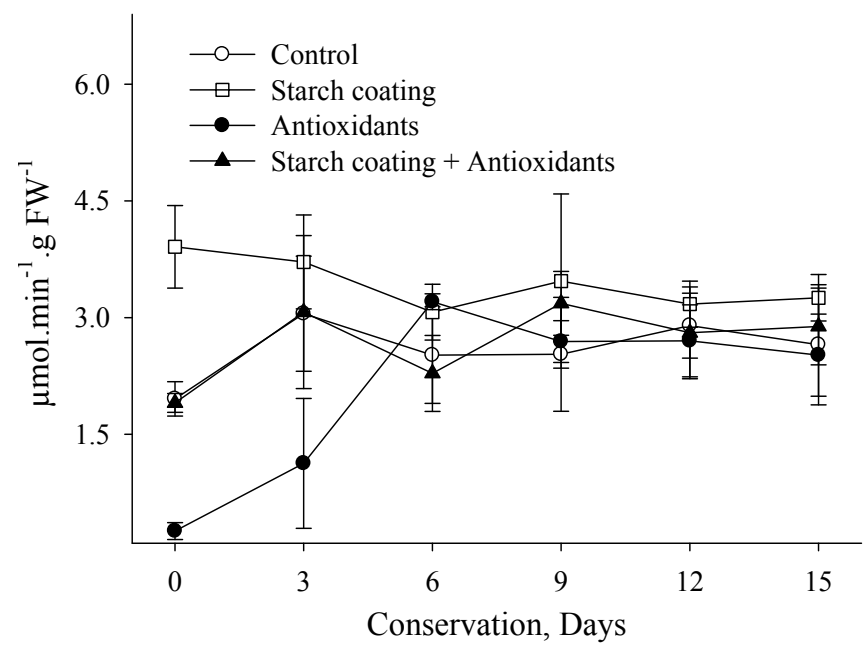

Figure 6. Poliphenol oxidase activity on fresh-cut sweet cassava, at $0,3,6,9,12$ and 15 days at $5 \pm 2{ }^{\circ} \mathrm{C}$ and $90 \pm 5 \% \mathrm{RH}$. The edible coating containing cassava starch (3\%) and antioxidants (Citric acid, $3 \%+$ Ascorbic acid, $3 \%$ ), and control (whithout edible coating and antioxidants).

The highest activity was observed in the treatment with the starch coating only, especially for the first days of storage, which may be related to the pronounced browning observed during storage, as evaluated by the visual assessment scores and blackened area values (Figures 1 and 2).

Application of the antioxidants reduced the enzymatic activity at the beginning of storage, as the enzymatic activity was 7.8-times lower than the control group on day 0 , and five-times lower on day 3 , which probably contributed to reduced browning. This may be related to the synergistic interaction between ascorbic and citric acids. Ascorbic acid is able to reduce quinones to phenols, supporting the higher phenol content observed with use of antioxidants (Figure 5). In addition to reducing the $\mathrm{pH}$, citric acid also acts as a copper chelator in the active site of PPO (AMODIO et al., 2011). Similar results have been reported by Calder et al. (2011), who used a solution containing $1 \%$ citric acid and $1 \%$ ascorbic acid, and observed a reduction in PPO activity in minimally-processed potatoes for up to 14 days.

There was a tendency for POD activity to increase with increasing storage time (Figure 7).

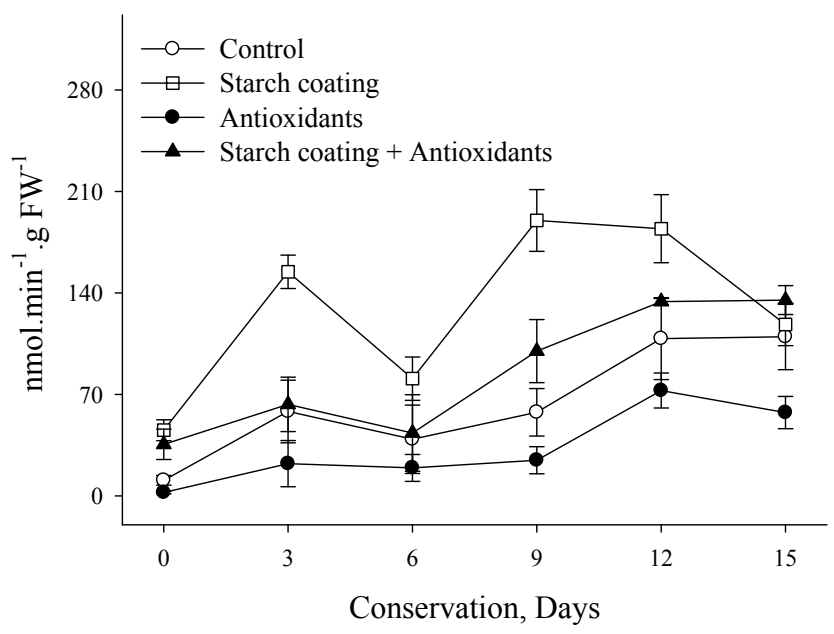

Figure 7. Peroxidase activity on fresh-cut sweet cassava, at $0,3,6,9,12$ and 15 days at $5 \pm 2^{\circ} \mathrm{C}$ and $90 \pm 5 \% \mathrm{RH}$. The edible coating containing cassava starch (3\%) and antioxidants (Citric acid, $3 \%+$ Ascorbic acid, $3 \%$ ), and control (whithout edible coating and antioxidants). 
Treatment with only the starch coating resulted in higher POD activity when compared to treatment with antioxidants only and the control group (Figure 7). High POD activity may have also contributed to increased browning, as although it assists in the removal of reactive oxygen species (formed as a result of mechanical cuts and injuries), high POD activity also produces blackened and insoluble pigments (IYER; MATTINSON; FELLMAN, 2010; LIMBO; PIERGIOVANNI, 2006). Thus, treatments containing antioxidants promoted a reduction in POD activity for all storage times compared to the control group, the coating only treatment, and the treatment containing antioxidants combined with coating, similar to that found by Melo and Vilas Boas (2006).

In the current study, we found that the use of anti-browning substances (citric and ascorbic acid) is a good alternative to minimize cutting injuries and reduce browning. In addition, we found that improvements still need to be made for the application of edible coatings to minimallyprocessed cassava. The drying time could potentially induce responses that lead to browning, therefore, reducing drying time may be a good alternative, supported by observations by Ojeda, Sgroppo and Zaritzky (2014).

\section{CONCLUSIONS}

The use of antioxidants (citric and ascorbic acid) was found to be effective for reducing browning in minimally-processed cassava, retaining its quality for 15 days at $5 \pm 2{ }^{\circ} \mathrm{C}$. Application of a combination of antioxidants and an edible coating was not found to confer any additional benefits compared to treatment with antioxidants alone.

\section{ACKNOWLEDGMENTS}

To CNPq and FACEPE for financial support.

\section{REFERENCES}

AGUILA, J. S. et al. Effect of antioxidants in fresh cut radishes during the cold storage. Brazilian Archives of Biology and Technology, Curitiba, v. 51, n. 6, p. 1217-1223, 2008.

AKA, J. et al. Modelling the interactions between free phenols, L-ascorbic acid, apple polyphenoloxidase and oxygen during a thermal treatment. Food Chemistry, London, v. 138, n. 2, p. 1289-1297, 2013.

AMODIO, M. L. et al. Post-cutting quality changes of fresh-cut artichokes treated with different anti-browning agents as evaluated by image analysis. Postharvest Biology and Technology, Amsterdam, v. 62, n. 2, p. 213-220, 2011.

ANDRADE, D. P. Estudo de diferentes cvs. de macaxeira (Manihot esculenta Crantz): Caracterização agronômica e adequação ao processamento mínimo. 2013. 97 f. Dissertação (Mestrado em Produção Vegetal: Área de Concentração em Produção Vegetal no Semiárido) Universidade Federal Rural de Pernambuco/Unidade Acadêmica de Serra Talhada, Serra Talhada, 2013.

ASSOCIATION OF OFFICIAL ANALYTICAL CHEMISTS INTERNATIONAL - AOAC. Official Methods Of Analysis of The Association of Official Analytical Chemists International. 16. ed. Washington: AOAC, v. 2, p. 37-45, 1997.

BOTREL, D. A. et al. Revestimento ativo de amido na conservação pós-colheita de pera Williams minimamente processada. Ciência Rural, Santa Maria, v. 40, n. 8, p. 1814-1820, 2010.

BOTREL, D. A. et al. Qualidade de alho (Allium sativum) minimamente processado envolvido com revestimento comestível antimicrobiano. Ciência e Tecnologia de Alimentos, Campinas, v. 27, n. 1, p. 32-38, 2007.

BOURTOOM, T. Edible films and coatings: characteristics and properties. International Food Research Journal, Serdang, v. 15, n. 3, p. 237-248, 2008.

CALDER, B. L. et al. The effectiveness of ozone and acidulant treatments in extending the refrigerated shelf life of fresh-cut potatoes. Journal of Food Science, Washington, v. 76, n. 8, p. 492-498, 2011

CAMPOS, R. P.; KWIATKOWSKI, A.; CLEMENTE, E. Post-harvest conservation of organic strawberries coated with cassava starch and chitosan. Revista Ceres, Viçosa, v. 58, n. 5, p. 554-560, 2011.

DUANGMAL, K.; APENTEN, R. K. O. A comparative study of polyphenoloxidases from taro (Colocasia esculenta) and potato (Solanum tuberosum var. Romano). Food Chemistry, London, v. 64 , n. 3, p. 351-359, 1999.

FERNANDES, L. S. et al. Efeito de antioxidantes sobre 0 escurecimento de batatas baroa minimamente processadas. Engenharia na Agricultura, Viçosa, v. 22, n. 3, p. 195-204, 2014. 
FERREIRA, D. F. Sisvar: a computer statistical analysis system. Ciência e Agrotecnologia, Lavras, v. 35, n.6, p. 1039-1042, 2011.

FOLIN, O.; CIOCALTEU, V. On tyrosine and tryptophane determinations in proteins. Journal of Biological Chemistry, New York, v. 73, n. 2, p. 627-650, 1927.

FREIRE, C. S. et al. Activity of oxidative enzymes involved in the browning of minimally processed sweet cassava (Manihot esculenta Crantz). Australian Journal of Crop Science, Sydney, v. 9, n. 4, p. 296-302, 2015.

FURTADO, M. C. Ação de revestimento comestível a base de amido e de antioxidante na conservação de inhame (Dioscorea spp.) minimamente processado. 2013. 60 f. Dissertação (Mestrado em Ciência e Tecnologia de Alimentos: Área de Concentração em Ciência e Tecnologia de Produtos Agrícolas) - Universidade Federal de Sergipe, São Cristóvão - SE. 2013.

IYER, S.; MATTINSON, D. S.; FELLMAN, J. K. Study of the early events leading to cassava root postharvest deterioration. Tropical Plant Biology, New York, v. 3, n. 3, p. 151-165, 2010.

JIMÉNEZ, A. et al. Edible and biodegradable starch films: a review. Food and Bioprocess Technology, New York, v. 5, n. 6, p. 2058-2076, 2012.

JUNQUEIRA, M. S. et al. Efeito de embalagens ativas no escurecimento enzimático de batatas (Solanum tuberosum) fatiadas e minimamente processadas. Semina: Ciências Agrárias, Londrina, v. 30, n. 3, p. 613-618, 2009.

LEE, M. Y.; LEE, M. K.; PARK, I. Inhibitory effect of onion extract on polyphenol oxidase and enzymatic browning of taro (Colocasia antiquorum var. esculenta). Food Chemistry, London, v. 105, n. 2, p. 528-532, 2007.

LIMBO, S.; PIERGIOVANNI, L. Shelf life of minimally processed potatoes: Part 1 . Effects of high oxygen partial pressures in combination with ascorbic and citric acids on enzymatic browning. Postharvest biology and technology, Amsterdam, v. 39, n. 3, p. 254-264, 2006.

LI, Y.; WILLS, R. B. H.; GOLDING, J. B. Sodium chloride, a cost effective partial replacement of calcium ascorbate and ascorbic acid to inhibit surface browning on fresh-cut apple slices. LWT-Food Science and Technology, New York, v. 64, n. 1, p. 503-507, 2015.

MALI, S.; GROSSMANN, M. V. E.;
YAMASHITA, F. Filmes de amido: produção, propriedades e potencial de utilização. Semina: Ciências Agrárias, Londrina, v. 31, n. 1, p. 137-156, 2010.

MEDEIROS, E. A. A. Deterioração pós-colheita de mandioca minimamente processada. 2009. $101 \mathrm{f}$. Tese (Doutorado em Fisiologia Vegetal: Área de Concentração em Controle da Maturação e Senescência em Órgãos Perecíveis). Universidade Federal de Viçosa, Viçosa, 2009.

MELO, A. A. M.; VILAS BOAS, E. V. B. Inibição do escurecimento enzimático de banana maçã minimamente processada. Ciência e Tecnologia de Alimentos, Campinas, v. 26, n. 1, p. 110-115, 2006.

MÉLO NETO, D. F. et al. Revestimento comestível a base de fécula de mandioca na conservação de mandioca de mesa minimamente processada. In: CONGRESSO BRASILEIRO DE MANDIOCA, 15., 20 Salvador. Anais... Salvador: SBM, 2013. p. 32-35.

OJEDA, G. A.; SGROPPO, S. C.; ZARITZKY, N. E. Application of edible coatings in minimally processed sweet potatoes (Ipomoea batatas L.) to prevent enzymatic browning. International Journal of Food Science and Technology, London, v. 49, n. 3, p. 876-883, 2014.

OLIVEIRA, T. V. et al. Desenvolvimento de técnicas para minimizar e analisar escurecimento em mandioca minimamente processada. In: SIMPÓSIO EM CIÊNCIA E TECNOLOGIA DE ALIMENTOS / CONGRESSO DO INSTITUTO NACIONAL DE FRUTOS, 1., 2010, Aracaju. Anais... Aracaju: UFS, 2010. p. 17-21.

OWITI, J. et al. iTRAQ-based analysis of changes in the cassava root proteome reveals pathways associated with post-harvest physiological deterioration. Plant Journal, London, v. 67, n. 1, p. 145-156, 2011.

ROCCULI, P. et al. Effects of the application of anti-browning substances on the metabolic activity and sugar composition of fresh-cut potatoes. Postharvest biology and technology, Amsterdam, v. 43, n. 1, p. 151-157, 2007.

SHAH, N. S.; NATH, N. Changes in qualities of minimally processed litchis: Effect of antibrowning agents, osmo-vacuum drying and moderate vacuum packaging. LWT - Food and Science Technology, New York, v. 41, n. 4, p. 660-668, 2008.

SIMÕES, A. N. et al. Edible coatings containing chitosan and moderate modified atmospheres maintain quality and enhance phytochemicals of 
carrot sticks. Postharvest Biology and Technology, Amsterdam, v. 51, n. 3, p. 364-370, 2009.

SIMÕES, A. N. et al. Effect of conservation temperature on quality and phenolic metabolism of intact and minimally processed kale leafs. Acta Scientiarum, Maringá, v. 37, n. 1, p. 101-107, 2015.

TOMÁS-BARBERÁN, F. A.; ESPÍN, J. E. Phenolic compounds and related enzymes as determinants of quality in fruits and vegetables. Journal of Agriculture and Food Chemistry, Washington, v. 811, n. 7, p. 853-876, 2001.

VALE, F. X. R. et al. Quant-a software to quantify plant disease severity, In: INTERNATIONAL WORKSHOP ON PLANT DISEASE EPIDEMIOLOGY, PROCEEDINGS OF THE INTERNATIONAL SOCIETY OF PLANT PHATOLOGY, 8., Viçosa. Anais... Viçosa: ISPP, 2001. p. 160. 